\title{
Analysis on the e-Learning Method in Malaysia with AHP-VIKOR Model
}

\author{
Lam Weng Siew, Lam Weng Hoe, Liew Kah Fai, Mohd Abidin Bakar, and Sim Jun Xian
}

\begin{abstract}
A lot of educational institutions are facing the problem in conducting the physical classes due to COVID-19 pandemic recently. Therefore, most of the medium of teaching has been changed from a face-to-face method to online teaching. These changes may create some challenges to the students as well as the teachers or lecturers. In fact, different learning methods have their own strengths and weaknesses. Therefore, this study aims to analyze the preference of E-learning method among the undergraduate students based on multiple criteria. This study determines the priority of decision criteria in the selection of learning methods among the undergraduate students using Analytic Hierarchy Process-VIseKriterijumska Optimizacija I Kompromisno Resenje (AHP-VIKOR) model. The decision criteria that considered in this study are quality management system, information quality, flexibility, learning and teaching as well as attractiveness. Besides, blended learning, distance learning, and e-learning are identified as the alternatives of the learning methods as well as the most preferred learning method is determined in this study. The results of this study show that the most preferred learning method among undergraduate students is E-learning, followed by distance learning, and finally blended learning. Flexibility, information quality, and quality management system are ranked as the top three influential decision criteria. The significance of this study is to determine the most preferred learning method as well as the most influential decision criteria in the selection of learning methods among undergraduate students with AHP-VIKOR model.
\end{abstract}

Index Terms-AHP-VIKOR, e-learning, distance learning, blended learning, priority.

\section{INTRODUCTION}

Nowadays, education system is important for every country in the world. The effectiveness of the education system reflects the development of a country. The country with a good education system is able to generate a knowledgeable and intelligent nation. In Malaysia, the most common learning method practiced by the educational institutions is blended learning. The undergraduate students have the opportunity to experience the other two learning methods recently which are distance learning and e-learning.

Blended learning is a hybrid learning method that consists of traditional on-campus education and computer-mediated or web-based portal such as Web-Based Learning Environment (WBLE). WBLE allows students to download learning materials such as lecture notes, tutorial questions,

Manuscript received May 22, 2020; revised November 4, 2020. This study is supported by Universiti Tunku Abdul Rahman, Malaysia.

The authors are with the Department of Physical and Mathematical Science, Faculty of Science, Universiti Tunku Abdul Rahman, Kampar Campus, Jalan Universiti, Bandar Barat, 31900 Kampar, Perak, Malaysia (e-mail: lamws@utar.edu.my,whlam@utar.edu.my, liewkf@utar.edu.my, abidin@utar.edu.my, simjunxian@1utar.edu.my). learning materials and assignments. WBLE eases the education by increasing the effectiveness of information sharing among the lecturers and students. The lecturers can interact with the students during the class.

Distance learning is a learning method similar to the traditional class which uses online broadcasts without a physical presence in the classroom. The learning materials are provided in the web-based portal. All submission of coursework is done online. Distance learning is more flexible in terms of location. Students can pursue their studies in any place with a stable internet connection. This allows the international students to complete their studies in their countries.

E-learning is a learning method in which students are taught and trained through an online medium. Interaction between the students and lecturers is done online through feedback in an online platform. E-learning is very flexible in terms of time and location because the courses can be done without restrictions on time and location. Students can attend the class anytime by watching the uploaded video and completing the tutorial questions when they are free. This helps the part-time students to adjust the schedule and allow them to complete their studies and work at the same time. On the other hand, E-learning is mainly based on self-discipline, the ability of self-regulation of students is the most significant requirement [1].

Based on the past studies, the important criteria such as quality management system, information quality, flexibility, learning and teaching as well as attractiveness are considered in this study in order to investigate the preference of learning methods among the undergraduate students [2]-[10]. Moreover, the sub-criteria from each decision criterion are considered in this study to determine the preference of learning methods among the undergraduate students.

Analytic Hierarchy Process (AHP) is a multi-criteria decision making (MCDM) model to determine the weights and priorities of decision criteria [11]-[14]. Moreover, AHP model is used to check the consistency of the decision-maker's evaluation, therefore decreasing the bias in the decision-making process [15]. AHP model can improve the reliability and validity of weighting in VIKOR model. On the one hand, VIseKriterijumska Optimizacija I Kompromisno Resenje (VIKOR) model is used to solve the decision problems with contradictory and non-commensurable criteria [16]-[18]. Furthermore, VIKOR model can also be utilized to rank the decision alternatives and determine the compromise solution that is the closest to the positive ideal solution (PIS) and farthest from the negative ideal solution (NIS). AHP-VIKOR model has been widely applied in the field of design concept evaluation [19], simulation software package [20], influenza intervention 
strategies [21], green design alternatives [22], hotel industry [23], global supplier selection [24], and commercial off-the-shelf (COTS) components [25].

Due to the robustness and effectiveness of the AHP-VIKOR model, therefore a conceptual framework is proposed in this study using AHP-VIKOR model. According to past studies, there is no comprehensive study done on the preference of learning methods among the undergraduate students in Malaysia with AHP-VIKOR model. Hence, this paper aims to fill the research gap by proposing a conceptual framework to determine the preference of learning methods among the undergraduate students by considering multiple criteria such as quality management system, information quality, flexibility, learning and teaching as well as attractiveness using AHP-VIKOR model. The remainder of this paper is organized as follows. Section II discusses about the data and methodology. The next section presents the data analysis, result and discussion of the study. The last section of this paper presents the concluding remarks and future recommendation of the study.

\section{DATA And Methodology}

\section{A. Conceptual Framework}

Table I presents the proposed conceptual framework to determine the preference of learning methods among blended learning, distance learning, and E-learning with AHP-VIKOR model.

TABLE I: PROPOSED CONCEPTUAL FRAMEWORK

\begin{tabular}{|c|c|}
\hline Level & \\
\hline Level 1 (Main objective) & Selection of learning methods \\
\hline \multirow[t]{5}{*}{ Level 2 (Decision criteria) } & Quality Management System \\
\hline & Information Quality \\
\hline & Flexibility \\
\hline & Learning and Teaching \\
\hline & Attractiveness \\
\hline \multirow[t]{4}{*}{ Level 3 (Sub-criteria) } & $\begin{array}{l}\text { 1. Quality Management System } \\
\text { Accessibility } \\
\text { Learnability } \\
\text { Support Offline } \\
\text { Stability } \\
\text { User Friendly } \\
\text { Well Organized }\end{array}$ \\
\hline & $\begin{array}{l}\text { 2. Information Quality } \\
\text { Appropriateness of Learning Object } \\
\text { Adequacy of Case Studies } \\
\text { Clarify of Material } \\
\text { Content Quality } \\
\text { Information Sharing } \\
\text { Up-to-date }\end{array}$ \\
\hline & $\begin{array}{l}\text { 3. Flexibility } \\
\text { Duration of Class } \\
\text { Time Flexibility } \\
\text { Location Flexibility }\end{array}$ \\
\hline & $\begin{array}{l}\text { 4. Learning and Teaching } \\
\text { Appropriateness of Evaluation } \\
\text { Interaction with Students } \\
\text { Pedagogy of Teaching }\end{array}$ \\
\hline
\end{tabular}

\begin{tabular}{ll} 
& 5. Attractiveness \\
& Course Design \\
& Enjoyment \\
& Multimedia Capability \\
& Webpage Design \\
& \\
Level 4 (Decision alternative) & Blended Learning \\
& Distance Learning \\
& E-learning \\
\hline \hline
\end{tabular}

Table I shows the hierarchy level for the learning methods' selection. As presented in Table I, the main objective of this study is to determine the preference of the undergraduate students in choosing the learning methods based on multiple decision criteria. The decision criteria consist of quality management, information quality, flexibility, learning and teaching, as well as attractiveness [2]-[10]. There are total of six sub-criteria from quality management system, six sub-criteria from information quality, three sub-criteria from flexibility, three sub-criteria from learning and teaching, and four sub-criteria from attractiveness. The learning methods that taken into consideration in this study are blended learning, distance learning, and E-learning. There are total of 140 undergraduate students from Universiti Tunku Abdul Rahman, Malaysia identified as the target respondents in this study.

\section{B. $A H P$}

AHP model is implemented to construct the pairwise comparison matrix (PCM) of decision criteria [11]-[14]. All the decision criteria and decision alternatives are compared in pairwise in order to obtain its relative importance to the main objective. AHP model is used to find the importance degrees of criteria. The steps of AHP are shown as follows [26].

Step 1: Identify the main goal, decision criteria, sub-criteria, and decision alternatives. The problem is decomposed into a hierarchical structure. There are four levels in the hierarchical structure.

Step 2: Compare all the decision criteria and decision alternatives in pairwise in order to obtain its relative importance to the main objective. The ratio scale for pairwise comparison as presented below.

\begin{tabular}{ll}
\multicolumn{2}{c}{ TABLE II: RATIO SCALE USED FOR PAIRWISE COMPARISON } \\
\hline \hline Scale & Meaning \\
\hline 1 & Equal importance of both elements. \\
3 & Weak importance of one element over another. \\
5 & $\begin{array}{l}\text { Essential or strong importance of one element over } \\
\text { another. }\end{array}$ \\
7 & Demonstrate importance of one element over another. \\
9 & Absolute importance of one element over another. \\
$2,4,6,8$ & Intermediate importance. \\
\hline \hline
\end{tabular}

Step 3: Create a PCM. The $n$ decision criteria PCM is as presented below.

$$
A=\left[\begin{array}{cccc}
a_{11} & a_{12} & \ldots & a_{1 n} \\
a_{21} & a_{22} & \ldots & a_{2 n} \\
\vdots & \vdots & \ddots & \vdots \\
a_{n 1} & a_{n 2} & \ldots & a_{n n}
\end{array}\right]
$$


where $a_{i j}$ is the degree of preference of element $i$ to element $j$.

Step 4: Normalize the matrix in order to determine the relative weights of each decision criterion.

Step 5: Check the consistency ratio $(C R)$ of the PCM. If the PCM demonstrates any inconsistency, then the decision-maker must re-evaluate or re-judge the preferences of the elements. The formula of $C R$ is presented below:

$$
C R=\frac{C I}{R I}
$$

where $C I=$ consistency index and $R I=$ random index [13].

$C R$ should be less than 0.10 in order to indicate that the pairwise comparisons in the PCM are considered to be adequately consistent [27]. This implies that AHP model yields meaningful results.

\section{VIKOR}

VIKOR is a MCDM model which can be utilized to rank the decision alternatives and determine the compromise solution that is the closest to the PIS and farthest from the NIS [16]. The advantage of the VIKOR model is to rank and choose the alternatives with multiple criteria [17], [18], [28]-[31]. Assuming that each decision alternative is evaluated according to multiple criterion functions, the compromise ranking is performed by comparing the measure of closeness to the ideal alternative [16], [17], [32]. The VIKOR is illustrated as follows [33]-[36].

Step 1: Determine the best $f_{j}^{*}$ and the worst $f_{j}{ }^{-}$values of all criteria functions, where $j=1,2, \ldots, n$.

Step 2: Compute the $S_{i j}$ for $i=1, \ldots, m, j=1, \ldots, n$. $m$ is the number of alternatives. $n$ is the number of criteria. $f_{i j}$ is refer to the score for alternative $i$ with criterion $j$.

$$
S_{i j}=\frac{w_{j}\left(f_{j} *-f_{i j}\right)}{\left(f_{j} *-f_{j}^{-}\right)}, i=1, \ldots, m, j=1, \ldots, n
$$

Step 3: Compute the $S_{i}, R_{i}$ and $Q_{i}$ values, $i=1, \ldots, m . v$ is the weight for the strategy of maximum group utility, whereas $1-v$ is the weight of the individual regret. These strategies could be compromised by $v=0.5$.

$$
\begin{aligned}
& S_{i}=\sum_{j=1}^{n} \frac{w_{j}\left(f_{j}^{*}-f_{i j}\right)}{\left(f_{j}^{*}-f_{j}^{-}\right)}, i=1, \ldots, m \\
& R_{i}=\max \frac{w_{j}\left(f_{j}^{*}-f_{i j}\right)}{\left(f_{j}^{*}-f_{j}^{-}\right)}, i=1, \ldots, m \\
& Q_{i}=v \frac{\left(S_{i}-S^{*}\right)}{\left(S^{-}-S^{*}\right)}+(1-v) \frac{\left(R_{i}-R^{*}\right)}{\left(R^{-}-R^{*}\right)}
\end{aligned}
$$

where

$$
\begin{aligned}
& S^{*}=\min \left(S_{i}, i=1, \ldots, m\right) \\
& S^{-}=\max \left(S_{i}, i=1, \ldots, m\right) \\
& R^{*}=\min \left(R_{i}, i=1, \ldots, m\right) \\
& R^{-}=\max \left(R_{i}, i=1, \ldots, m\right)
\end{aligned}
$$

Step 4: Rank the alternatives based on the $Q$ values [30], [37]. Propose the best alternative compromise solution by choosing the smallest $Q$ value.

\section{EMPIRICAL RESULTS}

Fig. 1 presents the priority of main decision criteria.

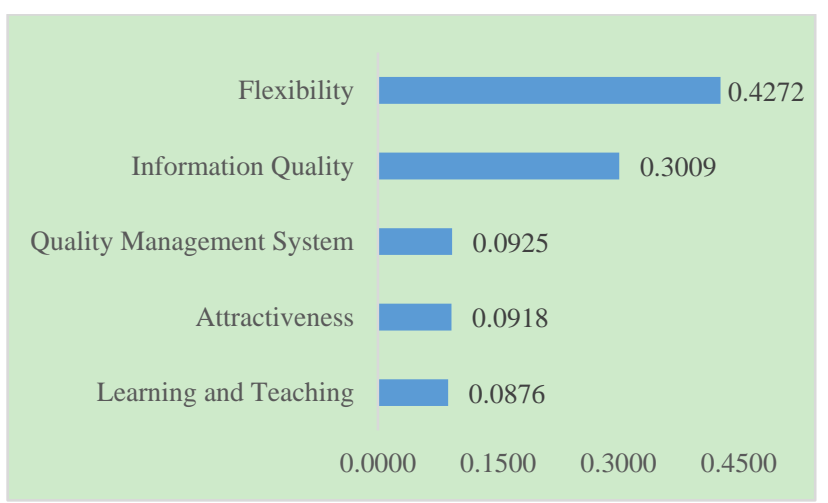

Fig. 1. Priority of main decision criteria.

Based on Fig. 1, flexibility has the highest weight (0.4272) and becomes the first criterion that considered by the undergraduate students in selection of learning methods. This is because the students prefer a more flexible time, duration, and location of the classes. This is mainly due to the limitation of on-campus learning in the campus. The second and third influential criteria are information quality and quality management system with a weight of 0.3009 and 0.0925 respectively. The students are more concerned about the high quality and useful information and knowledge provided in the learning material. Good quality of the information should consist of only the useful and important information. Besides, unnecessary information should be filtered out in order to increase the effectiveness of the study.

Quality management system is crucial in providing the teaching materials to the students through some web-based learning platforms. Moreover, the students also prefer to have a user friendly web-based learning platform, so that they can search the learning materials easily. Hence, quality management system is important for the students because it affects the efficiency of students in acquiring learning materials and information. The fourth criterion falls on the attractiveness with a weight of 0.0918 . The design of the webpage and course structure are covered in the attractiveness decision criterion. Students might not concern about the course structure as they must complete every subject in their courses.

The last criterion that the undergraduate students would consider is learning and teaching (0.0876). Learning and teaching consists of dissemination of information and evaluation of students. The reason to explain the fifth ranking might due to the students prefer to study by themselves compare to study in class. Hence, quality of teaching might not be the main concern of students in selecting the learning method. In summary, flexibility and information quality are quite important compared to quality management system, attractiveness, as well as learning and teaching in the preference of learning methods.

According to the results, the value of $C R$ is 0.024 which is well below 0.100 , this implies that the PCM of decision criteria is consistent. Hence, the results of this study are acceptable and reliable. 
Fig. 2 to Fig. 6 show the preference of weights of the sub-criteria based on each decision criterion.

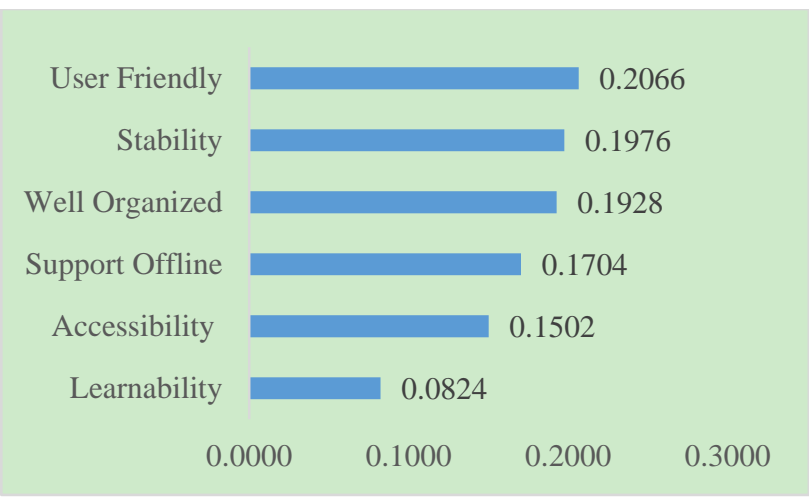

Fig. 2. Priority of sub-criterion based on quality management system.

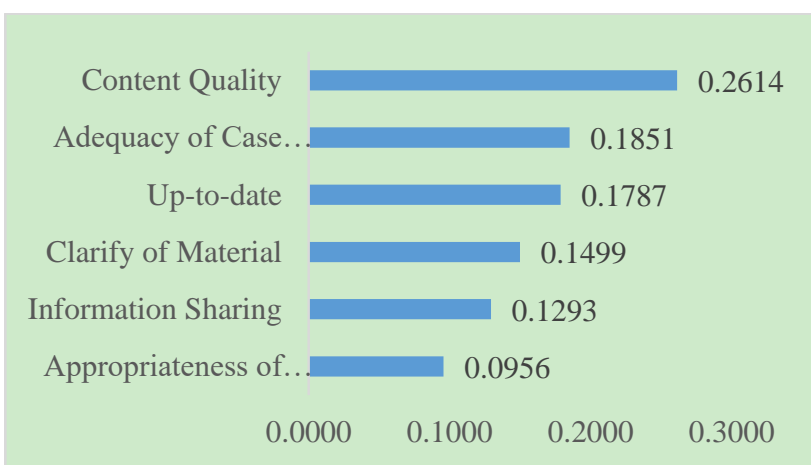

Fig. 3. Priority of sub-criterion based on information quality.

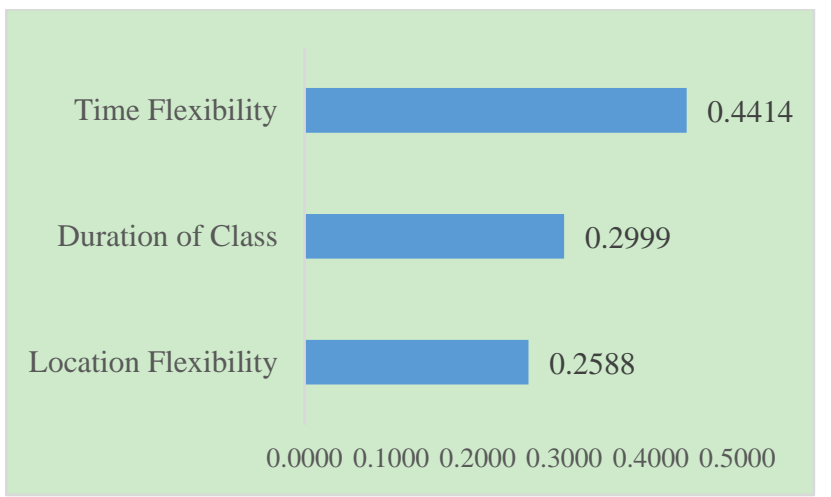

Fig. 4. Priority of sub-criterion based on flexibility.

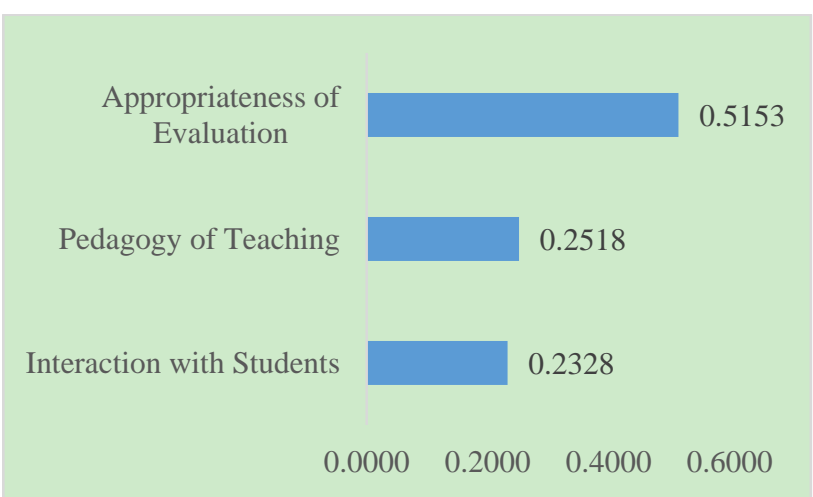

Fig. 5. Priority of sub-criterion based on learning and teaching.

In terms of quality management system, user friendly (0.2066), stability (0.1976), and well organized (0.1928) are the top three important sub-criteria. It is followed by support offline (0.1704), accessibility (0.1502), and lastly learnability (0.0824). For information quality, content is the most preferred sub-criteria with the highest weight of 0.2614 . It is followed by adequacy of case studies (0.1851), up-to-date (0.1787), clarify of material (0.1499), information sharing (0.1293), and finally appropriateness of learning object (0.0956). In terms of flexibility, time flexibility is the dominant sub-criterion with the highest weight of 0.4414 , followed by duration of class (0.2999) and location flexibility (0.2588). For learning and teaching, appropriateness of evaluation has the largest weights (0.5153) compared to pedagogy of teaching $(0.2518)$ and interaction with students (0.2328). In terms of attractiveness, course design obtains the first place in the ranking with the highest weight of 0.3631 . It is followed by enjoyment (0.2946), multimedia capability (0.1852), and lastly webpage design (0.1572).

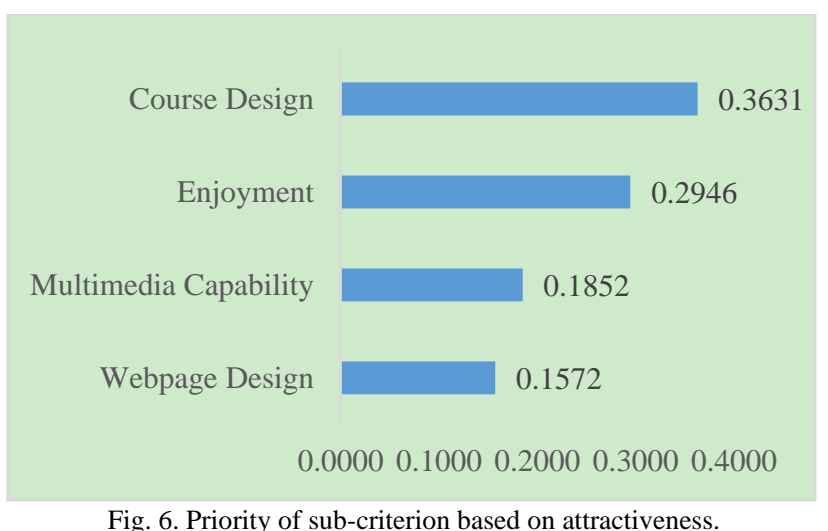

Table III demonstrates the weights of the decision criteria and sub-criteria.

\begin{tabular}{|c|c|c|c|c|c|}
\hline Criteria & $\begin{array}{l}\text { Weight } \\
\text { between } \\
\text { the } \\
\text { criteria }\end{array}$ & $\begin{array}{l}\text { Weight } \\
\text { within } \\
\text { the } \\
\text { criteria }\end{array}$ & $\begin{array}{l}\text { Ran } \\
\text { king }\end{array}$ & $\begin{array}{l}\text { Weight } \\
\text { among } \\
\text { the } \\
\text { sub-crite } \\
\text { ria }\end{array}$ & $\begin{array}{l}\text { Ran } \\
\text { king }\end{array}$ \\
\hline System Quality & 0.0925 & & & & \\
\hline Accessibility & & 0.1502 & 5 & 0.0139 & 21 \\
\hline Learnability & & 0.0824 & 6 & 0.0076 & 22 \\
\hline Support Offline & & 0.1704 & 4 & 0.0158 & 19 \\
\hline Stability & & 0.1976 & 2 & 0.0183 & 16 \\
\hline User Friendly & & 0.2066 & 1 & 0.0191 & 15 \\
\hline Well Organized & & 0.1928 & 3 & 0.0178 & 17 \\
\hline Information Quality & 0.3009 & & & & \\
\hline $\begin{array}{l}\text { Appropriateness of } \\
\text { Learning Object }\end{array}$ & & 0.0956 & 6 & 0.0288 & 11 \\
\hline $\begin{array}{l}\text { Adequacy of Case } \\
\text { Studies }\end{array}$ & & 0.1851 & 2 & 0.0557 & 5 \\
\hline Clarify of Material & & 0.1499 & 4 & 0.0451 & 8 \\
\hline Content Quality & & 0.2614 & 1 & 0.0787 & 4 \\
\hline Information Sharing & & 0.1293 & 5 & 0.0389 & 9 \\
\hline Up-to-date & & 0.1787 & 3 & 0.0538 & 6 \\
\hline Flexibility & 0.4272 & & & & \\
\hline Duration of Class & & 0.2999 & 2 & 0.1281 & 2 \\
\hline Time Flexibility & & 0.4414 & 1 & 0.1885 & 1 \\
\hline Location Flexibility & & 0.2588 & 3 & 0.1105 & 3 \\
\hline Teaching & 0.0875 & & & & \\
\hline $\begin{array}{l}\text { Appropriateness of } \\
\text { Evaluation }\end{array}$ & & 0.5153 & 1 & 0.0451 & 7 \\
\hline Interaction with & & 0.2328 & 3 & 0.0204 & 14 \\
\hline
\end{tabular}




\begin{tabular}{|c|c|c|c|c|c|}
\hline Pedagogy of Teaching & & 0.2518 & 2 & 0.0220 & 13 \\
\hline Attractiveness & 0.0918 & & & & \\
\hline Course Design & & 0.3631 & 1 & 0.0333 & 10 \\
\hline Enjoyment & & 0.2946 & 2 & 0.0271 & 12 \\
\hline Multimedia Capability & & 0.1852 & 3 & 0.0170 & 18 \\
\hline Webpage Design & & 0.1572 & 4 & 0.0144 & 20 \\
\hline
\end{tabular}

Fig. 7 shows the weights of all sub-criteria.

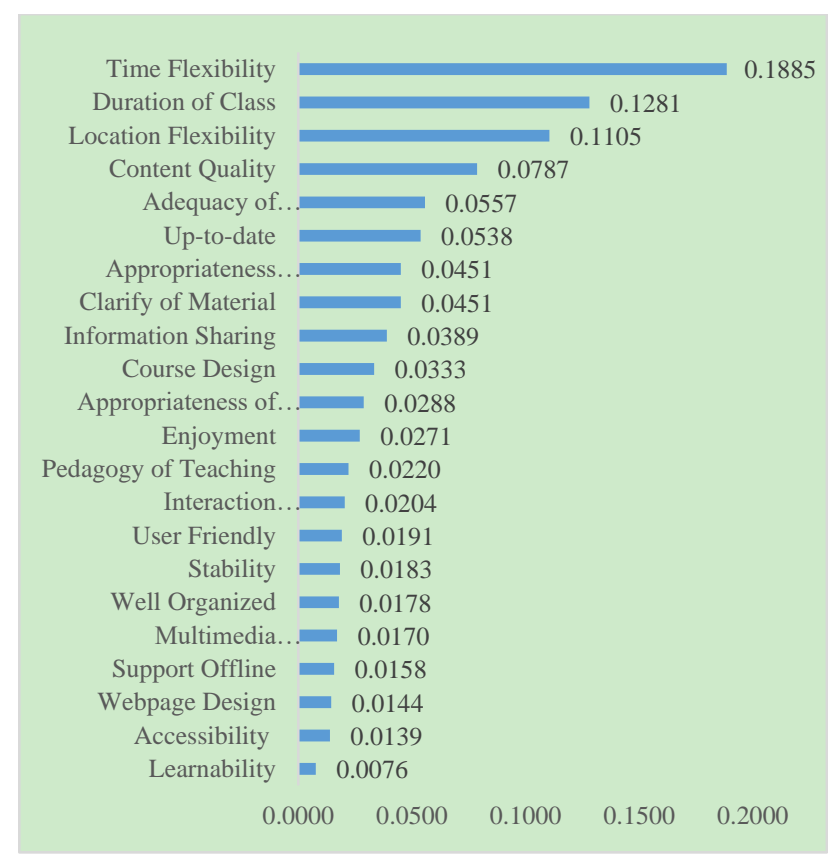

Fig. 7. Weights of all sub-criteria.

Based on Fig. 7, the top three influential sub-criteria that considered by the undergraduate students are time flexibility, duration of class, and location flexibility. The weights of time flexibility, duration of class, and location flexibility are $0.1885,0.1281$, and 0.1105 respectively. The importance of these sub-criteria is significant as the weights of these sub-criteria are the highest among the others. On the other hand, learnability has the lowest weights which is 0.0076 .

Table IV shows the best $f_{j}^{*}$ and the worst $f_{j}^{-}$values respect to each sub-criterion.

\begin{tabular}{lcc} 
TABLE IV: THE BEST $f_{j}$ * AND THE WORST & $f_{j}^{-}$VALUES FOR EACH \\
\hline CRITERION FUNCTIONS & & \\
\hline \hline Criteria & $f_{j}^{*}$ & $f_{j}^{-}$ \\
\hline Accessibility & 4.5714 & 3.0214 \\
Learnability & 4.4214 & 2.8571 \\
Support Offline & 4.3286 & 2.7643 \\
Stability & 4.7214 & 3.1857 \\
User Friendly & 4.4714 & 2.9357 \\
Well Organized & 4.5643 & 2.8429 \\
Appropriateness of Learning Object & 3.2214 & 2.8857 \\
Adequacy of Case Studies & 2.9357 & 2.5429 \\
Clarify of Material & 2.9857 & 2.7071 \\
Content Quality & 2.8929 & 2.5286 \\
Information Sharing & 3.0214 & 2.6286 \\
Up-to-date & 3.1357 & 2.8429
\end{tabular}

\begin{tabular}{lll} 
Duration of Class & 3.8857 & 2.9000 \\
Time Flexibility & 3.7500 & 2.8286 \\
Location Flexibility & 4.1643 & 3.1000 \\
Appropriateness of Evaluation & 2.9500 & 2.7357 \\
Interaction with Students & 3.0214 & 2.9000 \\
Pedagogy of Teaching & 2.9643 & 2.7714 \\
Course Design & 4.1571 & 3.2929 \\
Enjoyment & 3.7786 & 2.9000 \\
Multimedia Capability & 4.0286 & 2.9786 \\
Webpage Design & 3.8357 & 2.7500 \\
\hline \hline
\end{tabular}

The evaluation results and the ranking of learning methods with respect to $S_{j}, R_{j}$, and $Q_{j}$ are shown in Table $\mathrm{V}$.

\begin{tabular}{|c|c|c|c|c|c|c|}
\hline & $S_{j}$ & Ranking & $R_{j}$ & Ranking & $Q_{j}$ & Ranking \\
\hline $\begin{array}{l}\text { Blended } \\
\text { Learning }\end{array}$ & 0.6187 & 3 & 0.1885 & 3 & 1.0000 & 3 \\
\hline $\begin{array}{l}\text { Distance } \\
\text { Learning }\end{array}$ & 0.4650 & 2 & 0.0787 & 2 & 0.4348 & 2 \\
\hline $\begin{array}{l}\text { E-learni } \\
\text { ng }\end{array}$ & 0.1970 & 1 & 0.0451 & 1 & 0.0000 & 1 \\
\hline
\end{tabular}

According to the results, $S^{*}=0.1970, S^{-}=0.6187$, $R^{*}=0.0451, R^{-}=0.1885$ and $v=$ weight for the strategy of maximum group utility $=0.5$. In this study, there are total of three learning methods evaluated based on the sub-criteria. From Table $\mathrm{V}$, the values of $S, R, Q$, and ranking of the preference order of all alternatives have been determined. According to VIKOR model, the decision alternative with the lowest value of $Q$ are identified as the best alternative among the number of alternatives under consideration. Therefore, it can be observed that the best decision alternative is E-learning with $S, R$, and $Q$ of $0.1970,0.0451$, and 0.0000 , respectively. The ranking is followed by distance learning and blended learning. The $S, R$, and $Q$ values of distance learning are $0.4650,0.0787$, and 0.4348 , respectively. Finally, $S, R$, and $Q$ values of blended learning are $0.6187,0.1885$, and 1.0000, respectively. In summary, E-learning is concluded as the most preferred learning method among the undergraduate students in this study.

\section{CONCLUSION}

AHP-VIKOR model is proposed to analyze the preference of E-learning method among the undergraduate students. The significance of this study is to determine the most preferred learning method as well as the most influential decision criteria in the selection of learning methods among the undergraduate students with AHP-VIKOR model. The findings of this study indicate that the most preferred learning method is E-learning. This implies that E-learning has dominated other learning methods such as distance learning and blended learning. The results have shown that flexibility, information quality, and management quality system are the top three most influential decision criteria that considered by the undergraduate students. In future research, expanding the categories of the respondents is one of the recommendations 
in this study. The working adults and part time students could be considered and this would possibly improve the quality of the study. Furthermore, comparison among the academic performance of students pursuing different learning methods can be considered as well because it is a significant consideration in selecting the learning method. This study acts as a guidance for all educational institutions to determine the potential improvements of the learning methods based on the influential main and sub decision criteria.

\section{CONFLICT OF INTEREST}

The authors declare no conflict of interest.

\section{AUTHOR CONTRIBUTIONS}

Lam Weng Siew took responsibility in the construction of the proposed conceptual framework and supervised the research; Lam Weng Hoe took responsibility in the construction of the manuscript; Lam Weng Siew, Lam Weng Hoe, Mohd Abidin Bakar and Liew Kah Fai wrote the paper; Sim Jun Xian did the data collection and review on the past studies; all authors discussed the progress and results of the research and had approved the final version.

\section{ACKNOWLEDGMENT}

The study is supported by Universiti Tunku Abdul Rahman, Malaysia.

\section{REFERENCES}

[1] Y. Gulbahar and A. Apler, "Learning preferences and learning styles of online adult learners," International Education Journal, vol. 4, no. 4, pp. 270-278, 2004.

[2] N. Gorla, T. M. Somers, and B. Wong, "Organizational impact of system quality, information quality, and service quality," The Journal of Strategic Information Systems, vol. 19, no. 3, pp. 207-228, 2010.

[3] Y. H. Al-Mamary, A. Shamsuddin, A. Hamid, and N. Aziati, "The relationship between system quality, information quality, and organizational performance," International Journal of Knowledge and Research in Management \& e-Commerce, vol. 4, no. 3, pp. 7-10, 2014

[4] M. N. Muhammad and N. Cavus, "Fuzzy DEMATEL method for identifying LMS evaluation criteria," Procedia Computer Science, vol. 120, pp. 742-749, 2017.

[5] S. Ravipati, "Report: Blended learning requires modification and flexibility," 2017.

[6] P. Frank, "PSU's flexibility with online classes makes it easier to get a business education," Portlan Business Journal, 2018.

[7] A. Mazumdar, "Application of multi-criteria decision making (MCDM) approached on teachers' performance evaluation and appraisal," 2009.

[8] J. A. Downey, "Recommendations for fostering educational resilience in the classroom," Preventing School Failure: Alternative Education for Children and Youth, vol. 53, no. 1, pp. 56-64, 2008.

[9] M. Fedrizzi and A. Molinari, "A multi-expert fuzzy TOPSIS-based model for the evaluation of e-learning paths," in Proc. 8th Conference of the European Society for Fuzzy Logic and Technology (EUSFLAT-13), pp. 554-558, 2013.

[10] M. Kabak, E. Ozceylan, M. Dagdeviren, and T. Genc, "Evaluation of distance education websites: A hybrid multicriteria approach," Turkish Journal of Electrical Engineering \& Computer Sciences, vol. 25, no. 4, pp. 2809-2819, 2017.

[11] T. L. Saaty, The Analytic Hierarchy Process, New York: McGraw-Hill, 1980.

[12] T. L. Saaty, "Decision making with the analytic hierarchy process," Int. J. Services Sciences, vol. 1, no. 1, pp. 83-98, 2008.

[13] W. S. Lam, M. A. Bakar, W. H. Lam, J. W. Chen, and H. L. Ma "Evaluation on the preference of coffee shops among undergraduate students with analytic hierarchy process model," International Journal of Supply Chain Management, vol. 7, no. 4, pp. 209-215, 2018.

[14] W. H. Lam, W. S. Lam, K. F. Liew, and S. C. Wong, "Data driven decision analysis on the selection of course programmes with AHP-TOPSIS model," International Journal of Supply Chain Management, vol. 7, no. 4, pp. 202-208, 2018.
[15] T. O. Abdullah, S. S. Ali, N. A. Al-Ansari, and S. Knutsson, "Possibility of groundwater pollution in Halabja Saidsadiq Hydrogeological Basin, Iraq using modified DRASTIC model based on AHP and Tritium isotopes," Geosciences, vol. 8, no. 7, pp. 236-248, 2018.

[16] S. Opricovic, Multi-criteria Optimization of Civil Engineering Systems, Belgrade: Faculty of Civil Engineering, 1998.

[17] S. Opricovic and G. H. Tzeng, "Compromise solution by MCDM methods: A comparative analysis of VIKOR and TOPSIS," European Journal of Operational Research, vol. 156, no. 2, pp. 445-455, 2004.

[18] G. H. Tzeng, C. W. Lin, and S. Opricovic, "Multi-criteria analysis of alternative-fuel buses for public transportation," Energy Policy, vol. 33, pp. 1373-1383, 2005.

[19] G. N. Zhu, J. Hu, J. Qi, C. C. Gu, and Y. H. Peng, "An integrated AHP and VIKOR for design concept evaluation based on rough number," Advanced Engineering Informatics, vol. 29, no. 3, pp. 408-418, 2015.

[20] F. Samanlioglu and Z. Ayag, "A fuzzy AHP-VIKOR approach for evaluation of educational use simulation software packages," Journal of Intelligent \& Fuzzy Systems, vol. 37, no. 6, pp. 7699-7710, 2019.

[21] F. Samanlioglu, "Evaluation of influenza intervention strategies in Turkey with fuzzy AHP-VIKOR," Journal of Healthcare Engineering, 2019.

[22] G. Tian, M. Zhou, H. Zhang, and H. Jia, "An integrated AHP and VIKOR approach to evaluating green design alternatives," in Proc. 2016 IEEE 13th International Conference on Networking, Sensing, and Control (ICNSC), pp. 1-6, 2016.

[23] P. Digkoglou, A. Dragoslis, J. Papathanasiou, and V. Kostoglou, "Using AHP and VIKOR to evaluate the hotel industry of eight European countries," in Proc. Balkan Region Conference on Engineering and Business Education, vol. 3, no. 1, pp. 8-13, 2017.

[24] A. Awasthi, K. Govindan, and S. Gold, "Multi-tier sustainable global supplier selection using a fuzzy AHP-VIKOR based approach," International Journal of Production Economics, vol. 195, pp. 106-117, 2018.

[25] A. Rawashdeh, B. Matalkah, and A. Hammouri, "A hybrid AHP-VIKOR methodology to evaluate for adoption COTS database components based on usability," International Journal of Computer Applications in Technology, vol. 56, no. 4, pp. 264-274, 2017.

[26] W. L. Winston, Operations Research and Algorithms, Belmont: Brooks/Cole, 2004.

[27] T. Saaty, The Analytic Process: Planning, Priority Setting, Resources Allocation, Mcgraw: New York, NY, USA, 1980.

[28] S. Opricovic and G. H. Tzeng, "Multicriteria planning of post-earthquake sustainable reconstruction," Computer-Aided Civil and Infrastructure Engineering, vol. 17, no. 3, pp. 211-220, 2002.

[29] S. Opricovic and G. H. Tzeng, "Fuzzy multicriteria model for post-earthquake land-use planning," Natural Hazards Review, vol. 4, no. 2, pp. 59-64, 2003.

[30] S. Opricovic and G. H. Tzeng, "Extended VIKOR method in comparison with outranking methods," European Journal of Operational Research, vol. 178, no. 2, pp. 514-529, 2007.

[31] Y. P. Ou Yang, H. M. Shieh, and J. D. Leu, "A VIKOR-based multiple criteria decision method for improving information security risk," International Journal of Information Technology \& Decision Making, vol. 8, no. 2, pp. 267-287, 2009.

[32] G. H. Tzeng, M. H. Teng, J. J. Chen, and S. Opricovic, "Multicriteria selection for a restaurant location in Taipei," International Journal of Hospitality Management, vol. 21, no. 2, pp. 171-187, 2002.

[33] C. L. Chang and C. H. Hsu, "Multi-criteria analysis via the VIKOR method for prioritizing land-use restraint strategies in the Tseng-Wen reservoir watershed," Journal of Environmental Management, vol. 90, no. 11, pp. 3226-3230, 2009.

[34] A. H. Musfirah and A. G. Jaharah, "Magnesium and aluminum alloys in automotive industry," Journal of Applied Sciences Research, vol. 8 , no. 9, pp. 4865-4875, 2012.

[35] S. Radhika, D. S. Kumar, and D. Swapna, "VIKOR method for multi criteria decision making in academic staff selection," Journal of Production Research and Management, vol. 3, no. 2, pp. 30-35, 2013.

[36] M. Ali, A. Yadav, M. Anis, and R. K. Shah, "Evaluation of hazardous waste management by using VIKOR: A case study of USA States," Modern Applied Science, vol. 11, no. 1, pp. 180-187, 2017.

[37] L. I. Tong, C. C. Chen, and C. H. Wang, "Optimization of multi-response processes using the VIKOR method," The International Journal of Advanced Manufacturing Technology, vol. 31, no. 11-12, pp. 1049-1057, 2007.

Copyright (C) 2021 by the authors. This is an open access article distributed under the Creative Commons Attribution License which permits unrestricted use, distribution, and reproduction in any medium, provided the original work is properly cited (CC BY 4.0). 


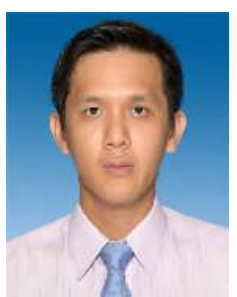

Lam Weng Siew is an assistant professor at the Department of Physical and Mathematical Science, Faculty of Science, Universiti Tunku Abdul Rahman (UTAR), Malaysia. He is also the head of programme for postgraduate programmes in Faculty of Science, UTAR. In addition, he is a professional technologist (MBOT), HRDF certified trainer, SAS certified statistical business analyst, graduate engineer (BEM) as well as associate $\operatorname{logistician}(\log \mathrm{M})$. His areas of expertise are optimization, multi-criteria decision making, data analytics, mathematical and statistical modelling, logistics and transportation.

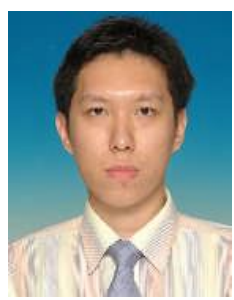

Lam Weng Hoe is an assistant professor at the Faculty of Science, Universiti Tunku Abdul Rahman (UTAR), Malaysia. He is also the head of the Department of Physical and Mathematical Science, UTAR. Furthermore, he is a professional technologist (MBOT) and associate logistician ( $\log M)$. His areas of expertise are multi-criteria decision making, optimization, financial modelling, data analytics as well as logistics and transportation.

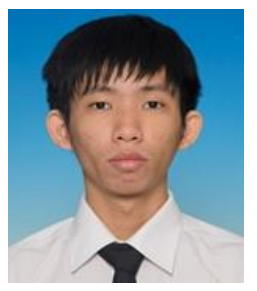

Liew Kah Fai is a lecturer at the Department of Physical and Mathematical Science, Faculty of Science, Universiti Tunku Abdul Rahman (UTAR), Malaysia. His areas of expertise are operations research and statistical modelling.

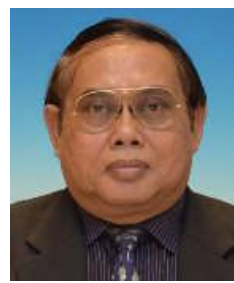

Mohd. Abidin Bakar is a lecturer at the Department of Physical and Mathematical Science, Faculty of Science, Universiti Tunku Abdul Rahman (UTAR), Malaysia. He is also a chartered member (CMILT) of the Chartered Institute of Logistics and Transport. His areas of expertise are business management, logistics and supply chain management.

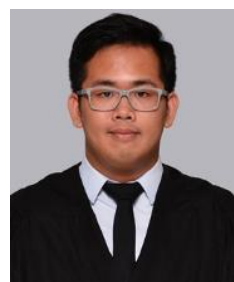

Sim Jun Xian is a graduate of the statistical computing and operations research programme, at the Department of Physical and Mathematical Science, Faculty of Science, Universiti Tunku Abdul Rahman (UTAR). 